\author{
DOI: 10.31866/2617-2674.4.1.2021.235066 \\ UDC 791.43:323.282
}

\title{
TERROR THROUGH SCREEN IMAGES AS A POWER DISCOURSE
}

\author{
Iryna Gavran ${ }^{1 \mathrm{a}}$, Olena Levchenko ${ }^{2 \mathrm{a}}$, Anastasiia Humen ${ }^{3 \mathrm{a}}$
}

${ }^{1}$ PhD in Pedagogy, Associate Professor; e-mail: yarynka.77@gmail.com; ORCID: 0000-0002-6777-3038

${ }^{2}$ Doctor of Sciences in Philosophy, Senior Researcher, Professor of Television Journalism and Acting Department; e-mail: levch@bigmir.net; ORCID: 0000-0002-0739-9777

${ }^{3}$ Master's Student at the Television Journalism and Acting Department; e-mail: radioactive1710@gmail.com; ORCID: 0000-0002-3588-5772

${ }^{a}$ Kyiv National University of Culture and Arts, Kyiv, Ukraine;

\section{Keywords:}

terror;

screen image;

screen arts;

manipulation;

influence;

modern television

\begin{abstract}
The purpose of the research is to analyze terror through screen images as a power discourse and to establish the role of an impact in the field of television art. Research methodology. The following methods were used: analysis and synthesis (the interdependence of the screen images, which are a kind of amplifier of intellectual potential on the screen, was analyzed); generalization (summary was made based on the analyzed links); systematization (all information collected during the research is systematized). The scientific novelty lies in the detailed consideration of the terror's components in the screen arts. An attempt to influence the modern viewer with "terrorist" images. Conclusions. During the research, the scientific achievements of domestic researchers on the topic of coverage of power discourse in the media and cinema were analyzed. The role of the power discourse's impact in the field of television art has been established. The peculiarities of screen images, their role and their influence on society have been revealed. The peculiarities of terror by screen images in the modern media space have been generalized. The impact of social networks and TV channels on the consciousness of people through manipulations has been determined.
\end{abstract}

For citation:

Gavran, I., Levchenko, O. and Humen, A. (2021). Terror through screen images as a power discourse. Bulletin of Kyiv National University of Culture and Arts. Series in Audiovisual Arts and Production, 4(1), pp.28-34.

\section{Problem statement}

In recent years modern television has become a major source of manipulation. Political and analytical programs have the greatest influence among all that is demonstrated live. Most of the images have a so-called terrorist character, which helps them find their audience. Nowadays similar projects still increase in the 
pursuit of ratings. Influence creates proposition and shows the trust of viewers.

When each program contains information that is needed not by the viewer, but by the TV channel, then the terrorist act becomes the main thing in all psychological states of a person. And the trust in false and manipulative information is greater than in real and verified information.

\section{Recent research and publications analysis.}

The topic of manipulation on television has been addressed by a small number of researchers. But some scientists have resorted to investigate terror-screen images. S. Datsiuk, V. Ivanov, N. Lihachev, S. Chernenko (2003) described the manipulation of the TV. H. Pocheptsov (2020) investigated power as communication and how the world is governed through communication. H. Chmil (2013) analyzed powerful role-playing and cinema as a disciplinary discourse of power.

The purpose of the research is to analyze terror through screen images as a powerful discourse and to establish the role of influence in the field of television art.

\section{Main research material}

In the 21st century, there is an "information war", which has the highest rate on television and is quickly transmitted from one viewer to another. This is most often seen during election campaigns and events that change history. A prime example is COVID-19, which turned the world upside down. Some are intimidated, and some continue to live their lives because they want to believe only in the best.

H. Pocheptsov (2011a) in his article "Power as communication" quite accu- rately described the current situation in the world: "The government has no other means of influence than communication. The way a person was becoming freer in history, the less remained in the state of opportunities for influence (except for communication). By the way, totalitarian power is also, first of all, communicative power. Its only and most significant feature is total control over the information and communication spaces. The democratic government also controls them, no matter how it denies it. But it does so by generating and maintaining a better information product".

In general, screen art is a kind of staging that has its features, staging and even roles. Thanks to this, the certain integrity of the screen and the person in front of it appears. The viewer becomes an integral part of this world and becomes an active user of the information provided to him (Chmil, 2013).

It is generally accepted that the key component of manipulation is to convince people of information that does not have accurate confirmation and consistency. It is called a suggestion. It is a process that has a huge impact on the psychological state of the viewer and is associated with a certain uncertainty, poor self-criticism and a lack of fulfilment in a favourite area. The easiest way to control the feelings of a person who does not have his/her own expressed "I" is in contemporary art. Such a person perceives the content of the information as an important attitude that affects her/ him and her/his environment (Datsiuk, 2003, p.43).

News, political and analytical programs use the suggestion process most clearly. This terrorist type helps, first of all, politicians in the electoral process to gain the required number of votes and to feel 
in their place. More often people cannot even recognize that they are being manipulated on purpose with a specific purpose. Although they may not feel terror at all. The spectator becomes a part of the game, which is beneficial to only one side.

Nowadays Ukrainian TV channels and their space belongs to politicians. They set trends for their screen programs. Who can be invited to broadcasts, show what and how to talk, what can be shown, facial expressions, gestures, images, commercials, words that can completely rebuild the viewer and leave the screen to analyze the situation? And this is what the target audience is based on, what it is interested in, how to keep it on its TV channel and make it trust every second of air.

The easiest way to enable manipulation is through the TV presenter. It is the entire program lever. He is the moderator and the crucial organizer of the live broadcast. The images created by the TV channel format help to set up interesting work and gather viewers at the screen.

Projects that involve viewers in the discussion have the highest performance among others. After all, a person becomes part of the topic and feels that his opinion can solve something or push for certain changes in a given situation. Just writing comments on social networks or the phone, will help you gather around certain "imaginary" people, like-minded people or at the same wavelength or people against everything that is said.

As practice shows, those who think the same way are much less. They are afraid to be like others, but they are easier to manipulate. Keeping on the psychological thread in them appears a screen image. On the one hand, it is a lever of electoral integrity, and on the other - a terrorist discourse.
The main percentage of power terror is carried out with the help of modern television. Today, TV screens act as a kind of pendulum that hypnotizes the viewer and conveys information that will be beneficial only to a certain caste of society, as a result of which a person, like a puppet, will follow certain imposed instructions, believing his/her actions to be correct.

Scientist and analyst H. Pocheptsov (2011a) believes that "today the state's communications with its citizens are based on a more objective and detailed basis than before. But our government still allows itself to experiment with society and teach it".

In one of his articles, $\mathrm{H}$. Pocheptsov analyzed the current terrorist television situation in the world and stated that "there is such a "spy" truth: "Who owns the information, he owns the world". But today a new managerial truth is more important: "By managing communication, we rule the world". By giving the mass consciousness certain facts and interpretations, selecting some and rejecting others, we create a concrete model of the world for it. Having received and accepted it, the mass consciousness can easily do without propaganda and external censorship, since now it will be able to determine for itself what is truth and what is false, although in accordance with the model introduced by someone".

The communicative component has become one of the mechanisms in the manipulation of 2020. All sources speak only of the killing coronavirus. At the same time, people began to forget that some situations and events are more important than character. From all monitors sounds that "we care about your life and health." The screen moved as far as possible from the themes of war, violence and murder, which are directly related to peace. 
"Words are power, but they become even more powerful when they sound from someone who is the authority for society. Ukraine has gradually lost its authority, but new ones do not appear. Today we have only "chair authorities" or authorities from show business or sports who can speak on all topics. And this is wrong since they are neither experts nor participants in the events", - this opinion was stated in his article "Communications between the government and society: new ways" H. Pocheptsov (2011b).

Scared people have a great tendency to stress, which means they are trusting and can themselves deliver manipulative information to their environment. Regardless of whether someone needs their opinion and its implementation or not.

Ukrainian politics has long lacked logical ideas. The authorities use the thoughts and options of the West. This is detrimental to work and communication in various spheres of life (Pocheptsov, 2011a).

Due to the developed imagination, in a certain layer of the Ukrainian population, television helps them to fantasize and get into a completely different world of events. Since many do not have enough positive emotions, special manipulation technologies are used to form their thinking in the paradigm of screen art and space. This is a definite manifesto of terror, between psychological, mental and imaginary fantasies (Chmil, 2013).

The modern viewer has lost the ability to recognize fakes in the era of postSoviet truth. This allowed him to be an influenced object. A person is no longer a problem for the state and for those who have money. They control the behaviour and consumption of information in simple ways (Pocheptsov, 2019b).

Not every viewer can overcome the modern flow of information. For some people, it's just communication, and for others, it's an important part of life.

Pocheptsov (2019c) noted that "information and communication are the base for structuring the world in nature, since there is a direct correlation between them. There are deviations, of course, when censorship or propaganda demands to say one thing, but in reality, something else is or should be".

Now the world is at the crossroads of new influential principles, to which some viewers are not yet ready. Countries express this through hybrid warfare. Every time a person becomes an object of terror and can get an attack on his psychological state (Pocheptsov, 2019b).

The need for manipulation in art and on the screen has existed before, but it has become more pronounced in the last six years, after the Revolution of Dignity in Kyiv. It was during this time that commu nication changed significantly. It seemed that everything had become transparent and truthful. And the emergence of social networks along with the work of television channels began to jointly influence the consciousness of people.

Ukrainian rating TV channels use all kinds of terror technologies. The huge difference is precisely between the behaviour of the presenter in the evening and night news broadcasts. S. Datsiuk (2003) notes that "in the nightly broadcasts, journalists "cut through" their voices, quite bold their assessments of events, they make the stories much more professional, more adhering to the principles of "good" journalism".

The quantity of political and analytical TV channels in Ukraine is increasing almost monthly. Viewers are ready to watch the broadcasts several times and begin to trust even the words of those who did not believe them before. 


\section{Conclusions}

It can be concluded that manipulation plays an integral role in the modern media space. Nearly every program on television wants the viewer to always remain with them and helped keep ratings. For their sake, political projects do not spare informational reasons and even create new ones. Influencing the viewer from the screen has already become a certain kind of art. When the program information can be simple to keep a man, the more difficult it to terrorize his brain to become for them the most simplified version. The question is whether in the future viewers will filter information, and not trust every spoken word from the TV screen. But the fact remains that it cannot last forever. Already historically, there are times of a revolution of consciousness and they change with every century. Now in Ukraine and the world, there is an "information war" about which everyone knows. And yet, manipulative factors and screen images manage to keep the bar.

\section{REFERENCES}

Datsiuk, S., Ivanov, V., Lihachova, N. and Chernenko, S., 2003. Manipuliatsii na TB [Manipulations on TV]. Kyiv: Telekrytyka Interniuz-Ukraïna.

Pocheptsov, H., 2011a. Vlada yak komunikatsiia [Power as communication]. MediaSapiens. [online] 22 May 2011. Available at: <https://ms.detector.media/manipulyatsii/post/9533/201105-22-vlada-yak-komunikatsiya/> [Accessed 03 September 2020].

Pocheptsov, H., 2011b. Komunikatsii mizh vladoiu ta suspilstvom: novi shliakhy [Communications between government and society: new ways]. MediaSapiens. [online] 14 April 2011. Available at: <https://ms.detector.media/manipulyatsii/post/9867/2011-04-14komunikatsii-mizh-vladoyu-ta-suspilstvom-novi-shlyakhy/> [Accessed 03 September 2020].

Pocheptsov, H., 2019a. My schitaem, chto nam peredaetsia informatciia, kogda na samom dele my poluchaem vliianie [We believe that information is transmitted to us when in fact we receive influence]. MediaSapiens. [online] 21 April 2019. Available at: <https://ms.detector.media/ mediaanalitika/post/22774/2019-04-21-my-schitaem-chto-nam-peredaetsya-informatsiyakogda-na-samom-dele-my-poluchaem-vliyanie/> [Accessed 03 September 2020].

Pocheptsov, H., 2019b. Propaganda i feiki v sistematike operatcii vliianiia [Propaganda of fakes in the taxonomy of operations of influence]. MediaSapiens. [online] 5 May 2019. Available at: <https://ms.detector.media/mediaanalitika/post/22821/2019-05-05-propaganda-y-feyky-vsystematyke-operatsyy-vlyyanyya/> [Accessed 03 September 2020].

Pocheptsov, H., 2019c. Upravliaiuchy komunikatsiieiu, my vodnochas upravliaiemo svitom [By managing communication, we also manage the world]. ZN.UA. [online] 22 February 2019. Available at: <https://zn.ua/ukr/SOCIUM/upravlyayuchi-komunikaciyeyu-mi-vodnochasupravlyayemo-svitom-303654_ html> [Accessed 03 September 2020].

Pocheptsov, H., 2020. Voiny novykh tekhnologii [Wars of new technologies]. Kharkiv: Folio.

Chmil, H.P., 2013. "Vladna" rolova diialnist i kino yak dystsyplinarnyi dyskurs vlady ["Powerful" role activity and cinema as a disciplinary discourse of power]. Kulturolohichna dumka, [online] 6, pp.33-37. Available at: <https://www.culturology.academy/wp-content/uploads/KD6_Chmil. pdf> [Accessed 03 September 2020]. 


\title{
ТЕРОР ЕКРАННИМИ ОБРАЗАМИ ЯК ВЛАДНИЙ ДИСКУРС
}

\author{
Ірина Гавран ${ }^{1 a}$, Олена Левченко ${ }^{2 a}$, Анастасія Гумен ${ }^{3 a}$ \\ ${ }^{1}$ кандидат педагогічних наук, доцент; \\ e-mail: yarynka.77@gmail.com; ORCID: 0000-0002-6777-3038 \\ 2 доктор філософських наук, старший науковий співробітник, професор кафедри тележурналістики \\ та майстерності актора; e-mail: levch@bigmir.net; ORCID: 0000-0002-0739-9777 \\ ${ }^{3}$ магістрант кафедри тележурналістики та майстерності актора; \\ e-mail: radioactive1710@gmail.com; ORCID: 0000-0002-3588-5772 \\ а Київський національний університет культури і мистецтв, Київ, Україна
}

\begin{abstract}
Анотація
Мета дослідження - проаналізувати терор екранними образами як владний дискурс та встановити роль впливу у сфері телевізійного мистецтва. Методологія дослідження. Використано такі методи: аналіз та синтез (проаналізовано взаємозалежності екранних образів, які є своєрідним підсилювачем інтелектуального потенціалу на екрані); узагальнення (на основі проаналізованих посилань сформовано висновки); систематизація (вся інформація, зібрана під час наукового дослідження, систематизована). Наукова новизна полягає у детальному розгляді складових терору в екранному мистецтві. Схарактеризовано спробу впливу «терористичними» образами на сучасного глядача. Висновки. Під час дослідження було проаналізовано наукові доробки вітчизняних дослідників на тему висвітлення владного дискурсу в мас-медіа та кіно. Встановлено роль впливу владного дискурсу у сфері телевізійного мистецтва та зазначено, що він створює пропозицію, виявляє довіру від глядачів. Виявлено особливості екранних образів, їх роль та вплив на суспільство. Узагальнено особливості терору екранними образами в сучасному медіапросторі. Визначено, що соціальні мережі разом з телеканалами впливають на свідомість людей за допомогою маніпуляцій.
\end{abstract}

Ключові слова: терор; екранний образ; екранне мистецтво; маніпуляція; вплив; сучасне телебачення

\section{ТЕРРОР ЭКРАННЫМИ ОБРАЗАМИ КАК ВЛАСТНЫЙ ДИСКУРС}

\author{
Ирина Гавран ${ }^{1 a}$, Елена Левченко ${ }^{2 a}$, Анастасия Гумен ${ }^{3 a}$ \\ 1 кандидат педагогических наук, доцент; \\ e-mail: yarynka.77@gmail.com; ORCID: 0000-0002-6777-3038 \\ 2 доктор философских наук, старший научный сотрудник, профессор кафедры тележурналистики \\ и мастерства актера; e-mail: levch@bigmir.net; ORCID: 0000-0002-0739-9777 \\ ${ }^{3}$ магистрант кафедры тележурналистики и мастерства актера; \\ e-mail: radioactive1710@gmail.com; ORCID: 0000-0002-3588-5772 \\ а Киевский национальный университет культуры и искусств, Киев, Украина
}

\section{Аннотация}

Цель исследования - проанализировать террор экранными образами, как властный дискурс и установить роль влияния в сфере телевизионного искусства. Методология исследования. Использованы такие методы: анализ и синтез (проанализирована взаимозависимость экранных 
образов, которые являются своеобразным усилителем интеллектуального потенциала на экране); обобщение (на основе проанализированных ссылок сформированы выводы); систематизация (вся информация, собранная во время научного исследования, систематизированная). Научная новизна заключается в детальном рассмотрении составляющих террора в экранном искусстве. Охарактеризована попытка влияния «террористическими» образами на современного зрителя. Выводы. В ходе исследования были проанализированы научные труды отечественных исследователей на тему освещения властного дискурса в массмедиа и кино. Установлена роль влияния властного дискурса в сфере телевизионного искусства и указано, что он создает предложение, проявляет доверие от зрителей. Выявлены особенности экранных образов, их роль и влияние на общество. Обобщены особенности террора экранными образами в современном медиапространстве. Определено, что социальные сети наряду с телеканалами влияют на сознание людей с помощью манипуляций.

Ключевые слова: террор; экранный образ; экранное искусство; манипуляция; влияние; современное телевидение 